\title{
Internal Control Effectiveness and Business Survival: Evidence from Thai Food Businesses
}

\author{
Kornchai PHORNLAPHATRACHAKORN ${ }^{1}$, Khajit NA KALASINDHU ${ }^{2}$
}

Received: September 10, 2020 Revised: November 08, 2020 Accepted: November 16, 2020

\begin{abstract}
This study aims at investigating the effects of internal control effectiveness on business survival of food businesses in Thailand through the mediators of productivity improvement and value creation. In this study, 155 food businesses in Thailand are the samples of the study. The results show that internal control effectiveness has a significant influence on productivity improvement and business survival. Productivity improvement critically affects value creation and business survival while value creation is an important determinant of business survival. However, internal control effectiveness has no relationship with value creation. Also, productivity improvement explicitly mediates the internal control effectiveness-business survival relationships. In summary, internal control effectiveness can enhance firms' sustainable competitive advantage, superior performance and long-term survival. Firms need to focus on internal control effectiveness through investing their assets and resources and utilizing their abilities, competencies and capabilities in order to continuously develop and improve their appropriate concepts and characteristics in an organization. Better internal control effectiveness definitely leads to more long-term survival. To generalize the research results, future research needs to collect data from other businesses and industries. Increased response rate of the study is important for future research to verify and confirm the research results.
\end{abstract}

Keywords: Internal Control Effectiveness, Business Survival, Productivity Improvement, Value Creation

JEL Classification Code: M41, M40

\section{Introduction}

Nowadays, firms are dealing with rigorously competitive business markets and environments, namely globalization, technological changes, customer demand diversity, product innovation, and new coming capable competitors. They need to apply and utilize their valuable techniques and strategies to compete in the markets and environments. These techniques and strategies can enhance sustainable competitive advantage and competitiveness and achieve superior performance, success, survival, and sustainability. Generally, firms have understood

${ }^{1}$ First Author and Corresponding Author. Associate Professor, Faculty of Management Sciences and Information Technology, Nakhon Phanom University, Thailand [Postal Address: Nai Mueang, Mueang Nakhon Phanom District, Nakhon Phanom 48000, Thailand]

Email: kornchai.p@npu.ac.th

${ }^{2}$ Assistant Professor, Faculty of Management Sciences and Information Technology, Nakhon Phanom University, Thailand. Email:khajit.nk@npu.ac.th

(c) Copyright: The Author(s)

This is an Open Access article distributed under the terms of the Creative Commons Attribution Non-Commercial License (https://creativecommons.org/licenses/by-nc/4.0/) which permits unrestricted non-commercial use, distribution, and reproduction in any medium, provided the original work is properly cited. and analyzed competitive situations and conditions, integrated existing knowledge from several disciplines, and present best business approaches through effective techniques and strategies for fitting with current and future operations. Successful techniques and strategies reflect firms' useful capabilities to long-term stability, growth and survival. In this study, internal control systems become beneficial strategic mechanisms in helping firms improve their operational effectiveness, create their organizational values and encourage their growth and survival in future and long-term perspectives. They represent good governance, corporate social responsibility and business ethics in firms' businesses. Thus, the effectiveness of internal control system is important for succeeding, surviving and sustaining in uncertain environments.

Interestingly, internal control effectiveness plays an important role in determining productivity improvement, value creation, and business survival. Here, internal control effectiveness is the ability of firms to assure for compliance objectives, reporting objectives, and business objectives and strategic goals (Wang, 2015). It can ensure a degree of firms' business operations provided for a realization of related goals and achieved targets, a level of their reported accounting numbers conforming to generally accepted accounting 
principles and fairly reflecting a substance of firms' economic transactions, and a scope of their compliances with applicable laws and regulations (Krishnan \& Yu, 2012). Firms with effective internal control can increase the effectiveness of operations, reduce an occurrence of fraudulent financial reporting and promote valuable legal and regulation practices (Anh, Thi, Quang, \& Thi, 2020). Thus, internal control effectiveness positively affects firms' business outcomes.

In addition, successful implementation of internal control effectiveness can affect productivity improvement, value creation and business survival. Firstly, productivity improvement is defined as effectively transforming inputs (labors, facilities, equipment, and inventories) into achieving maximized firm outputs (Jacobs, Kraude, \& Narayanan, 2016). It increases outputs with minimizing inputs or holding constant inputs, provides the most efficient use of inputs assuming constant outputs and enhances using existing assets more efficiently and their abilities to substitute resources and capabilities for one another (Dave \& Sohani, 2019). Secondly, value creation refers to the results of pooling and accumulating firms' heterogeneous resources and capabilities through the developments of innovative products and services (Schneider \& Sachs, 2017). It can help the firm compete throughout environmental changes, exploit relational capabilities and respond to customers (Bouncken, Fredrich, Kraus, \& Ritala, 2020). Thus, value creation can affect firms' best performance and long-term sustainability. Thirdly, business survival is an expression of firms' abilities to successfully react to rapidly changing environments (Korunka, Kessler, Frank, \& Lueger, 2010). It reflects a constitutive indicator and a fundamental pointer of sustainable business success in future and longterm perspectives (Dao, 2019). Accordingly, internal control effectiveness is hypothesized to have a positive effect on productivity improvement, value creation and business survival in this study.

In this study, food businesses in Thailand are the appropriate samples of the study because these businesses are majorities of Thailand' employment, national incomes, country development, and growth promotion. Also, the Thai government has supported these businesses as priorities of important industries in Thailand by allocating budgets and investments to these industries. Here, the objective of this study is to investigate the effects of internal control effectiveness on business survival of food businesses in Thailand. The key research question is how internal control effectiveness has an effect on business survival. The specific research questions are (a) how internal control effectiveness affects productivity improvement, value creation, and business survival, (b) how productivity improvement affects value creation and business survival, (c) how value creation affects business survival, and (d) how productivity improvement and value creation mediate the internal control effectiveness-business survival relationships.

\section{Literature Review and Hypotheses Development}

In the dynamic capability theory, dynamic capability is an ability of firms to devise new resources and reconfigure existing ones to address issues that arise in the external environments (Teece, Pisano, \& Shuen, 1997). Firms with effective dynamic capability can identify required resources and capabilities and renew and bundle their current resources and capabilities to enhance organizational performance. In this study, the dynamic capability theory is utilized to explain the research relationships in the conceptual model. Internal control effectiveness is considered as the dynamic capability because it must be congruent with environmental situations that are dynamic continuously. Then, internal control effectiveness becomes a source of firms' competitive advantage and performance. Here, internal control effectiveness is proposed as a key determinant of driving productivity improvement, value creation and business survival. Thus, the research relationships of these variables are discussed and hypothesized. The conceptual model presents the aforementioned relationships, as shown in Figure 1.

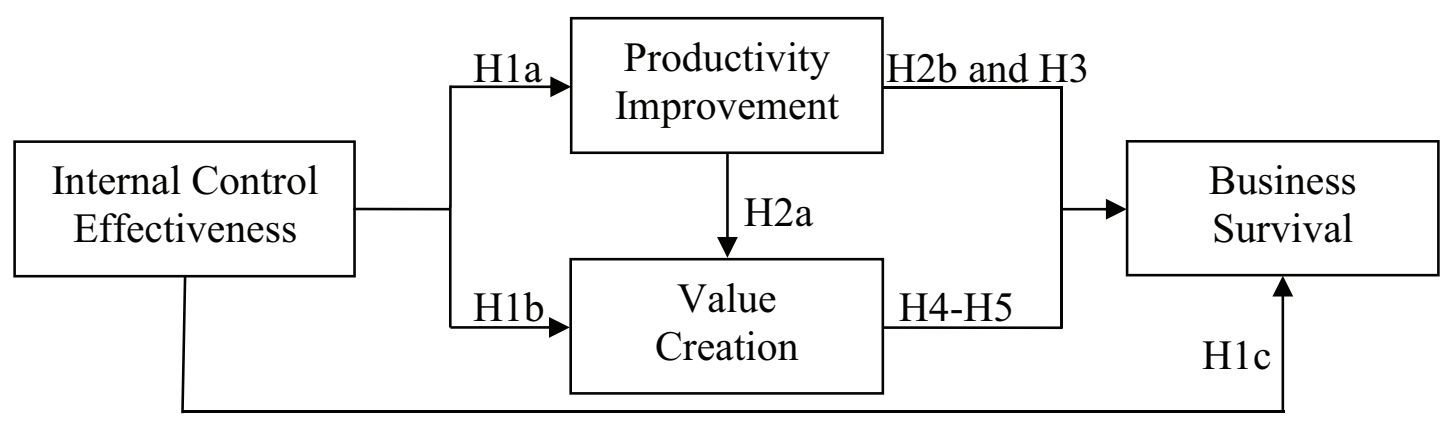

Figure 1: The conceptual model of the relationships between internal control effectiveness and business survival 
Kornchai PHORNLAPHATRACHAKORN, Khajit NA KALASINDHU /

\subsection{Internal Control Effectiveness}

Generally, the Committee of Sponsoring Organizations of the Treadway Commission (COSO) is a joint initiative to combat corporate fraud. It has dedicated to guiding executive management and government entities in relevant aspects of organizational governance, business ethics, internal control, business risk management, fraud and financial reports (Franzoni \& Pelizzari, 2019). COSO which published the "Internal Control Integrated Framework" which has designed to help businesses establish, assess and enhance their internal control. The COSO framework defines internal control as a process, carried out by the board of directors, the administration and other personnel of an entity, designed to provide "reasonable security" with respect to the achievement of objectives, including the effectiveness and efficiency of the operations, the reliability of financial reports, and the compliance with applicable laws and regulations (Lari Dashtbayaz, Salehi, \& Safdel, 2019). The COSO internal control framework consists of five interrelated components as control environment, risk assessment, control activities, information and communication, and monitoring derived from the way in which the administration manages a business (Hazami-Ammar, 2019). According to the COSO internal control framework, these components provide an effective framework to describe and analyze the internal control system implemented in an organization.

Internal control has become a valuable strategic mechanism of firms' awareness of corporate social responsibility and business ethics (Chen, Ma, Shi, Tu, \& Xu, 2020; Husnaini \& Basuki, 2020; Tran, Lam, \& Luu, 2020). It can enhance operational efficiency and effectiveness, reliability, transparency and integrity of financial statements, information usefulness and value, and compliance with laws, regulations, rules, and other related issues. Thus, effective internal control is important for firms' performance and survival. Here, internal control effectiveness is the main driver of increased superior performance and long-term survival. Internal control effectiveness is defined as an ability of firms to assure compliance objectives, reporting objectives, and business objectives and strategic goals (Wang, 2015). It can ensure a degree of firms' business operations and practices provided for a realization of related goals and achieved targets. Higher internal control effectiveness positively leads to better performance and success and longer survival in an organisation. Also, internal control effectiveness provides valuable benefits to market participants. It can ensure that reported accounting numbers conform to generally accepted accounting principles and fairly reflect a substance of firms' economic transactions (Shon \& Weiss, 2009). It explicitly improves a reliability of financial statements, decreases information risks, prevents a misappropriation of assets, and adequately fulfills stewardship responsibilities. Firms with internal control effectiveness can have lowering a cost of equity capital. In addition, internal control effectiveness has potential contributions to effective and efficient operations, enhanced reliability of financial reporting and compliance with applicable laws and regulations (Krishnan \& Yu, 2012). It is a foundation for high-quality financial reporting by reducing an occurrence of fraudulent financial reporting. Accordingly, maintaining effective internal control is a basic requirement of firms' sustainable operations in complex business environments.

Internal control effectiveness becomes a central issue in corporate governance and refers to firms' abilities to provide reasonable assurance regarding achievement of effectiveness and efficiency of operations, reliability of financial reporting and compliance with regulations (Chang, Yen, Chang, \& Jan, 2014). It assures that firms conduct their operational efficiency and in accordance with their mission statements, their management data and financial reporting are reliable (Lansiluoto, Jokipii, \& Eklund, 2016). It promotes compliance with applicable laws and regulations. Firms with effective internal control can respond to risks, accomplish performance and profitability goals, safeguard resources against loss, report any control weaknesses with corrective actions, and commit to laws and regulations which firms are subject to. Moreover, achieving internal control effectiveness, firms need to focus on control environment, risk assessment, control activities, information and communication, and monitoring (Chen, Smith, Cao, \& Xia, 2014). They are required to set realistic objectives, provide sufficient resources to pursue them and address a range of activities in transaction cycles and other strategic areas to achieve their objectives. Also, firms need to identify operational risks through a process of risk assessment, communicate information about threats and changes by producing operational, financial and compliance-related reports and monitor functions of internal controls and ensure meeting their objectives (Anh, Thi, Quang, \& Thi, 2020). In the effectiveness of internal controls, firms can improve and increase their business operations and productivities. They tend to have a significant positive influence on productivity improvement and also create potential organizational benefits and contributions and firm values in the longterm perspectives. Hence, successful internal control effectiveness is likely to enhance firms' growth, survival and sustainability in volatile competitive environments. Thus, internal control effectiveness is hypothesized to have a positive relationship with productivity improvement, value creation and business survival. Therefore,

H1: Internal control effectiveness has a positive effect on (a) productivity improvement, (b) value creation and (c) business survival. 


\subsection{Productivity Improvement}

Here, productivity improvement is defined as increased efficiency of converting inputs into outputs in order to produce desired products (Geum, Shin, \& Park, 2011). It reflects the growth rate of outputs to inputs through utilization, efficiency, effectiveness, and quality of useful resources, including materials, labors, machines, and funding to produce qualified goods and services. Firms with productivity improvement can enhance their sustainable competitive advantage, superior performance and survived success. In addition, productivity improvement refers to efficiently and effectively transforming inputs (labors, facilities, equipment, and inventories) into achieving maximized firm outputs (Jacobs, Kraude, \& Narayanan, 2016). It focuses on trading off between inputs and outputs. Firms with productivity improvement can increase outputs with minimizing inputs or holding constant inputs, provide the most efficient use of inputs assuming constant outputs and enhance using existing assets more efficiently and their abilities to substitute resources and capabilities for one another (Dave \& Sohani, 2019). Also, productivity improvement presents a business approach that seeks to find and eliminate causes of mistakes and defects in business processes by focusing on desired outputs (Desai, 2013). It utilizes input resources in a transformation process to co-create value with customers (Zolnowski, Semmann, Amrou, \& Bohmann, 2013). It enables firms to produce more outputs without increasing their inputs. Firms can have more cost leadership and increase their sales through utilizing productivity improvement. Thus, productivity improvement is essential for increasing firm value, encouraging current profitability and promoting future performance and long-term survival. Hence, productivity improvement is hypothesized to have a positive relationship with value creation and business survival. Likewise, this study proposes productivity improvement as a mediator of the research relationships because it can help indirectly link internal control effectiveness to business survival. Therefore,

H2: Productivity improvement has a positive effect on (a) value creation and (b) business survival.

H3: Productivity improvement mediates the internal control effectiveness-business survival relationships.

\subsection{Value Creation}

Value creation is the second consequence of potentially implementing internal control effectiveness. Great value creation explicitly results from successful internal control effectiveness implementation. In this study, value creation refers to the results of pooling and accumulating firms' heterogeneous resources and capabilities through developments of innovative products and services (Schneider \& Sachs, 2017). It is beneficial to build and enhance in high levels of performance and success. Firms with value creation can achieve sustainable competitiveness and continuous business survival and growth. Similarly, value creation is defined as the process by which firms make use of their resources and capabilities in order to generate values (Kahkonen \& Lintukangas, 2012). These values comprise firms' abilities to compete and respond to environmental change, exploit relational capabilities and understand and respond to customers (Bouncken, Fredrich, Kraus, \& Ritala, 2020).

Firms with great value creation can develop new products, respond to customer needs and market requirements, increase sustainable competitive advantage, and enhance performance, success and survival in an organization (Zacharias, Nijssen, $\&$ Stock, 2016). Thus, value creation reflects to an ability of firms to utilize their valuable resources and capabilities for generating their competitiveness and superior performance in the future and long-term operations. In addition, measurements of value creation include a monetary worth of technical, economic, service, and social benefits which firms receive an exchange of their market offerings and customers' payments and gain from their reputation, relationship quality, trust, customer satisfaction, and customer retention (Matthyssens, Bocconcelli, Pagano, \& Quintens, 2016). It can help build a stronger relationship with customers, ensure more loyal and satisfied customers, understand a better insight on customers' behaviours, provide valuable ideas to customers, and become best designers and marketers in responding to customers (Baltova \& Baltov, 2017). More value creation can result in firms' better performance and longer survival and sustainability. Then, value creation matters and it tends to have a significant positive influence on business survival. Similarly, value creation is proposed as a mediator of the internal control effectiveness-business survival relationships because it can help indirectly leads internal control effectiveness to business survival. Therefore,

H4: Value creation has a positive effect on business survival.

H5: Value creation mediates the internal control effectiveness-business survival relationships.

\subsection{Business Survival}

Business survival is an important dependent variable of the research relationship. Here, business survival is defined as an expression of firms' abilities to successfully react to rapidly changing environmental conditions and situations (Korunka, Kessler, Frank, \& Lueger, 2010). It reflects a long-term performance, growth, success, and stability. It is considered as a constitutive indicator and a fundamental pointer of sustainable business success in future and long-term perspectives (Dao, 2019). Firms with business survival can achieve outstanding long-term success, namely profitability (revenues and profits), financial condition (costs of debts and equity and sources of funding), innovation (new products and services, new operations and new businesses), customer loyalty (existing customer retention and new customer increase), and continuous growth (sales growth and 
Kornchai PHORNLAPHATRACHAKORN, Khajit NA KALASINDHU /

return on sales growth) (Stafford, Danes, \& Haynes, 2013). Accordingly, business survival is positively affected by valuable factors and consequences, including internal control effectiveness, productivity improvement and value creation.

\section{Research Methods}

\subsection{Sample Selection and Data Collection}

Food businesses in Thailand are continuously growing according to dynamic changes, globalization and customer demands. Customers need to have good health, increased quality and safety of food products. These businesses have committed with these requirements and needs and been aware of society and environmental impacts. Thus, they must implement valuable strategic mechanism as internal control effectiveness in enhancing and encouraging their operations, practices and activities to successfully meet business goals, objectives and targets. Accordingly, food businesses in Thailand from Thai Food Processors Association (www. thaifood.org) and the Food and Drug Administration (www. fda.moph.go.th) are the appropriate samples of the study. To achieve aforementioned outcomes, internal audit department has functioned an independent, objective assurance and consulting activity designed to add value to and improve an organization's operations. It helps an organization accomplish its objectives by bringing a systematic, disciplined approach to evaluate and improve the effectiveness of risk management, internal control and governance processes by providing insight and recommendations based on analyses and assessments of data and business processes and value to governing bodies and senior management with commitment to integrity and accountability as an objective source of independent advice.

Thus, the key informants of these businesses as internal audit executives, namely internal audit directors, internal audit managers or internal audit heads are appropriate because they have taken the highest responsibilities of internal audit and internal control functions, duties and responsibilities and other related activities in an organization. Their practices and perceptions relating to internal control activities and outcomes are explicitly emphasized. This study collects and gathers the data from all 797 food businesses in Thailand by using a mail survey procedure via questionnaire. With regard to the questionnaire mailing, the valid mailing was 770 surveys, from which 159 responses were received. Of the surveys completed and returned, 155 were usable. The effective response rate was approximately $20.13 \%$. If the response rate for a mail survey, with an appropriate follow-up procedure, are greater than $20 \%$ are considered acceptable according to Aaker, Kumar, and Day (2001). Thus, the response rate is useful for testing the research relationships in the study. Also, proving potential non-response bias and detecting possible problems with nonresponse errors are investigated by using a comparison of the first and the second wave data as recommended by Armstrong and Overton (1977). In this regard, neither procedure showed significant differences because there were no statistically significant differences between first and second groups at a $95 \%$ confidence level as firm age $(\mathrm{t}=0.10, \mathrm{p}>.05)$, firm size $(\mathrm{t}=0.13, \mathrm{p}>.05)$ and firm capital $(\mathrm{t}=0.11, \mathrm{p}>.05)$.

\subsection{Measures}

All constructs were measured using a 5-point Likert scale ( 1 = strongly disagree to $5=$ strongly agree), except for firm age, firm size and firm capital. Sources of measurements for these constructs are self-developed from existing literatures as shown in Table 1. Measurements of these constructs are self-developed from existing literature of internal control effectiveness, productivity improvement, value creation, and business survival as shown in Appendix A. Internal control effectiveness is the independent variable of the study and it refers to the ability of firms to assure for compliance objectives, reporting objectives, and business objectives and strategies goals (Wang, 2015). Five-item scale was developed to assess how firms have implemented their abilities, competencies and capabilities to meet business goals, objectives and targets, namely efficiency of operations and other related issues. Also, productivity improvement is the mediating variable of the study and it is defined as an increased efficiency of converting inputs into outputs in order to produce desired products (Geum, Shin, \& Park, 2011). Five-item scale was established to measure how firms have increased the ratio growth of outputs to inputs through utilisation, efficiency, effectiveness, and quality of useful resources and assets. Similarly, value creation is the mediating variable of the study and it is the results of pooling and accumulating firms' heterogeneous resources and capabilities through developments of innovative products and services (Schneider \& Sachs, 2017).

Five-item scale was initiated to evaluate how firms build a stronger relationship with customers, ensure more loyal and satisfied customers, understand a better insight on customers' behaviours, provide valuable ideas to customers, and become the best designers and marketers in responding to customers. Next, business survival is the dependent variable of the study and it is defined as an expression of firms' abilities to successfully react to rapidly changing environmental conditions and situations (Korunka, Kessler, Frank, \& Lueger, 2010).

Table 1: Sources of measurements for all variables

\begin{tabular}{|l|c|l|}
\hline Variables & Items & \multicolumn{1}{|c|}{ Sources } \\
\hline $\begin{array}{l}\text { Internal control } \\
\text { effectiveness (IC) }\end{array}$ & 5 & $\begin{array}{l}\text { Anh, Thi, Quang, \& Thi } \\
(2020)\end{array}$ \\
\hline $\begin{array}{l}\text { Productivity } \\
\text { improvement (PI) }\end{array}$ & 5 & Dave \& Sohani (2019) \\
\hline Value creation (VC) & 5 & $\begin{array}{l}\text { Bouncken, Fredrich, } \\
\text { Kraus, \& Ritala (2020) }\end{array}$ \\
\hline $\begin{array}{l}\text { Business survival } \\
\text { (BS) }\end{array}$ & 7 & Dao (2019) \\
\hline
\end{tabular}


Seven-item scale was utilized to gauge how firms achieve sale revenues, profits, sales growth, profit growth, new products and services, existing customer retention, and new customer increase. Lastly, firm age, firm size and firm capital are considered as the control variables of the study to verify the research relationships. Firm age is measured by the number of years a firm has been in existence, firm size is measured by the number of employees in the firm and firm capital is measured by the amount of money a firm has invested in doing business.

\subsection{Test of Research Instrument}

Within verifying the validity of the study, confirmatory factor analysis was utilized to gauge the underlying relationships of a large number of items and to determine whether they can be reduced to a smaller set of factors. Thus, all factor loadings as values of 0.41-0.96 are greater than the 0.40 cut-off and are statistically significant (Nunnally \& Bernstein, 1994). Also, discriminant power was utilized to assess the validity of the measurements by item-total correlation. In the scale validity, item-total correlations as values of $0.40-0.80$ are greater than 0.30 (Churchill, 1979). Lastly, the reliability of the measurements was evaluated by Cronbach alpha coefficients. In the scale reliability, Cronbach alpha coefficients as values of $0.80-0.90$ are greater than 0.70 (Nunnally \& Bernstein, 1994). The scales of all measures express an acceptable validity and reliability in this study. Accordingly, the quality of the research instrument is acceptably considered. Table 2 presents the results for factor loadings, item-total correlation and Cronbach alpha for multiple-item scales used in this study.

\subsection{Statistical Technique}

In this study, both structural equation model and ordinary least square regression analysis are considered as the appropriate statistical techniques for testing the research relationships in the study. To test the research relationships, this study applies the structural equation model (SEM) as an appropriate approach to test these research relationships.

Table 2: Results of measure validation

\begin{tabular}{|l|c|c|c|}
\hline Items & $\begin{array}{c}\text { Factor } \\
\text { Loadings }\end{array}$ & $\begin{array}{c}\text { Item-total } \\
\text { correlation }\end{array}$ & $\begin{array}{c}\text { Cronbach } \\
\text { alpha }\end{array}$ \\
\hline $\begin{array}{l}\text { Internal control } \\
\text { effectiveness } \\
\text { (IC) }\end{array}$ & $0.41-0.86$ & $0.43-0.62$ & 0.80 \\
\hline $\begin{array}{l}\text { Productivity } \\
\text { improvement } \\
\text { (PI) }\end{array}$ & $0.68-0.92$ & $0.40-0.56$ & 0.90 \\
\hline $\begin{array}{l}\text { Value creation } \\
\text { (VC) }\end{array}$ & $0.73-0.91$ & $0.50-0.77$ & 0.87 \\
\hline $\begin{array}{l}\text { Business } \\
\text { survival (BS) }\end{array}$ & $0.79-0.96$ & $0.57-0.80$ & 0.89 \\
\hline
\end{tabular}

It fits the composite approach previously discussed and is the safest option when estimating data from an unknown population (Sarstedt, Hair, Ringle, Thiele, \& Gudergan, 2016). To test the internal control effectiveness-business survival relationships, ordinary least square (OLS) regression analysis is also conducted because all variables in this study were neither nominal data nor categorical data. In the existing literature, a comparison between SEM and OLS methods has been explained. The model of SEM method is much better compared to OLS model method based on its fitness and accuracy (Aimran \& Ahmad, 2013). In order to avoid error in the results of regression analysis, the underlying assumptions are employed to verify, such as linearity, normality, multicollinearity, auto-correlation, and heteroscedasticity (Osborne \& Waters, 2001). All underlying assumptions are verified and their results are considerably accepted. However, to verify and confirm the existing literature, this study has utilised both methods in the study. Accordingly, the results of this study are presented in the next section.

\section{Results and Discussion}

Table 3 shows the descriptive statistics and correlation matrix for all variables. Multicollinearity might occur when inter-correlation in each predict variable is more than 0.80 , which is a high relationship (Hair, Black, Babin, \& Anderson, 2010). The correlations ranging from 0.25 to 0.74 at the $p<0.05$ level, which means that the possible relationships of the variables in the conceptual model could be tested. Similarly, variance inflation factors (VIFs) were used to provide information on the extent to which nonorthogonality among independent variables inflates standard errors. The VIFs range from 1.04 to 2.35 , well below the cut-off value of 10 as recommended by Neter, Wasserman, and Kutner (1985), means that the independent variables are not correlated with each other. Thus, there are no substantial multicollinearity problems encountered in this study.

Table 4 presents the results of path coefficients and hypotheses testing of the research relationships. Figure 2 shows a summary of the internal control effectivenessbusiness survival relationships. In this study, the goodness of fit of the models, including the goodness of fit index (GFI), the comparative fit index (CFI), the incremental fit index (IFI), and the root mean square error of approximation (RMSEA) are considered (Herda \& Lavelle, 2012). This study shows that the initial test of the measurement model resulted in a good fit to the data. Firstly, CFI value as 0.91 lies between 0 and 1 , with values over 0.90 indicating a relatively good fit (Bentler, 1990). Secondly, GFI value as 0.92 is an index that ranges from 0 to 1 , with value over 0.90 indicating a relatively good fit (Byrne, 1998). Thirdly, IFI value exceeding 0.90 as 0.92 indicates a relatively good fit (Kline, 1998). Lastly, a RMSEA value of less than 0.05 as 0.04 indicates a close fit and less than 0.08 suggests a marginal fit (Bollen \& Long, 
1993). Likewise, to investigate the effects of internal control effectiveness on business survival, the results of OLS regression analysis of the research relationships are presented in Table 5.

In this study, the results indicate that internal control effectiveness is positively related to productivity improvement $(\mathrm{b}=0.20, \mathrm{p}<0.09 ; \mathrm{b}=0.40, \mathrm{p}<0.08)$ and business survival $(\mathrm{b}=0.28, \mathrm{p}<0.06 ; \mathrm{b}=0.54, \mathrm{p}<$ 0.02 ). It is a significant driver of changing productivity improvement and business survival. In existing literature, internal control effectiveness is the ability of firms to assure for compliance objectives, reporting objectives, and business objectives and strategic goals (Wang, 2015). It provides valuable benefits to effective and efficient operations, enhanced reliability of financial reporting and compliance with applicable laws and regulations (Krishnan $\&$ Yu, 2012). Firms with internal control effectiveness can respond appropriately to risks, accomplish performance and profitability goals, safeguard resources against loss, report any control weaknesses with corrective actions, and commit to laws and regulations which firms are subject to. They can improve and increase their business operations and productivities that lead to their sustainable competitiveness, outstanding success and long-term survival. Accordingly, internal control effectiveness is likely to have a positive influence on productivity improvement and business survival. Greater internal control effective importantly relates to more productivity improvement and longer business survival. Thus, internal control effectiveness positively affects productivity improvement and business survival. Therefore, Hypotheses 1a and 1c are supported. Surprisingly, internal control effective has no influence on value creation $(b=0.06, p<0.63 ; b=0.29, p<0.11$ ). Within the effectiveness of internal controls, firms are required to set realistic objectives, provide sufficient resources to pursue them and address a range of activities in transaction cycles and other strategic areas to achieve their objectives (Chen, Smith, Cao, \& Xia, 2014). They can meet business objectives, strategies goals and operational targets. However, value creation may result from doing extraordinary business practices, practices, functions, and duties while internal control effectiveness does not present excellent works in rapidly competitive markets and environments. Then, internal control effectiveness may not link to value creation in an organization. Therefore, Hypothesis $1 \mathrm{~b}$ is not supported.

Table 3: Descriptive statistics and correlation matrix

\begin{tabular}{|c|c|c|c|c|}
\hline Variables & IC & PI & VC & BS \\
\hline Mean & 4.23 & 3.96 & 3.97 & 3.86 \\
\hline Standard deviation & 0.44 & 0.58 & 0.63 & 0.60 \\
\hline \multicolumn{5}{|l|}{ Internal control effectiveness (IC) } \\
\hline Productivity improvement $(\mathrm{PI})$ & $0.54^{* *}$ & & & \\
\hline Value creation (VC) & 0.25 & $0.74^{\star * *}$ & & \\
\hline Business survival (BS) & $0.35^{\star *}$ & $0.72^{* * *}$ & $0.71^{* * *}$ & \\
\hline
\end{tabular}

${ }^{* *} p<.05,{ }^{* * *} p<.01$

Table 4: Results of path coefficients and hypotheses testing

\begin{tabular}{|l|c|c|c|c|}
\hline Hypotheses & Relationships & Coefficients & Standard Error & t-value \\
\hline $\mathrm{H} 1 \mathrm{a}$ & $\mathrm{IC} \rightarrow \mathrm{PI}$ & $0.20^{*}$ & 0.12 & 1.70 \\
\hline $\mathrm{H} 1 \mathrm{~b}$ & $\mathrm{IC} \rightarrow \mathrm{VC}$ & 0.06 & 0.12 & 0.49 \\
\hline $\mathrm{H} 1 \mathrm{c}$ & $\mathrm{IC} \rightarrow \mathrm{BS}$ & $0.28^{*}$ & 0.15 & 1.92 \\
\hline $\mathrm{H} 2 \mathrm{a}$ & $\mathrm{PI} \rightarrow \mathrm{VC}$ & $1.09^{* * *}$ & 0.37 & 2.94 \\
\hline $\mathrm{H} 2 \mathrm{~b}$ & $\mathrm{PI} \rightarrow \mathrm{BS}$ & $0.58^{* *}$ & 0.40 & 2.00 \\
\hline $\mathrm{H} 3$ & $\mathrm{IC} \rightarrow \mathrm{PI}$ & $0.20^{*}$ & 0.12 & 1.70 \\
\hline $\mathrm{H} 4$ & $\mathrm{PI} \rightarrow \mathrm{BS}$ & $0.58^{* *}$ & 0.40 & 2.00 \\
\hline $\mathrm{H} 5$ & $\mathrm{VC} \rightarrow \mathrm{BS}$ & $0.57^{* *}$ & 0.29 & 1.97 \\
& $\mathrm{IC} \rightarrow \mathrm{VC}$ & 0.06 & 0.12 & 0.49 \\
\hline
\end{tabular}

${ }^{*} \mathrm{p}<.10,{ }^{* *} \mathrm{p}<.05,{ }^{* * *} \mathrm{p}<.01$ 


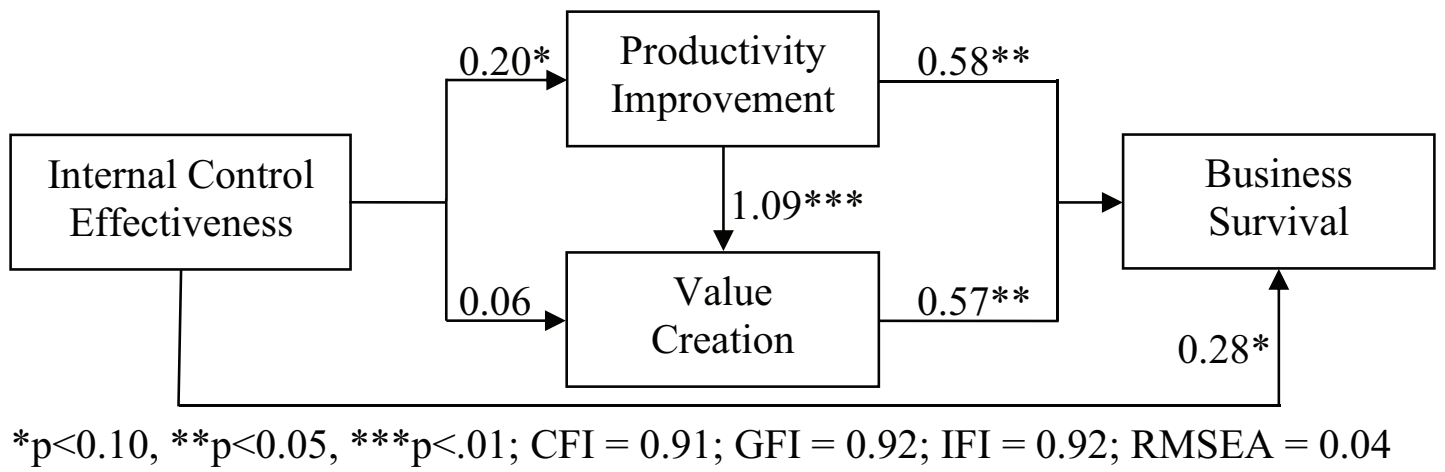

Figure 2: A summary of the internal control effectiveness-business survival relationships

Table 5: Results of OLS regression analysis ${ }^{a}$

\begin{tabular}{|c|c|c|c|c|c|c|c|}
\hline \multirow{2}{*}{$\begin{array}{l}\text { Independent } \\
\text { Variables }\end{array}$} & \multicolumn{7}{|c|}{ Dependent Variables } \\
\hline & PI & vc & BS & vc & BS & BS & BS \\
\hline \multirow[t]{2}{*}{ IC } & $0.40^{*}$ & 0.29 & $0.54^{* *}$ & & & 0.27 & 0.28 \\
\hline & $(0.22)$ & $(0.17)$ & $(0.22)$ & & & $(0.17)$ & $(0.17)$ \\
\hline \multirow[t]{2}{*}{$\mathrm{PI}$} & & & & $0.55^{\star * *}$ & $0.40^{\star \star}$ & $0.68^{* * *}$ & \\
\hline & & & & $(0.09)$ & $(0.17)$ & $(0.13)$ & \\
\hline \multirow[t]{2}{*}{ VC } & & & & & $0.61^{* * *}$ & & $0.93^{* * *}$ \\
\hline & & & & & $(0.23)$ & & $(0.17)$ \\
\hline \multirow[t]{2}{*}{ FA } & -0.16 & -0.13 & -0.14 & -0.04 & 0.02 & -0.03 & -0.02 \\
\hline & $(0.12)$ & $(0.09)$ & $(0.12)$ & $(0.07)$ & $(0.09)$ & $(0.09)$ & $(0.09)$ \\
\hline \multirow[t]{2}{*}{ FS } & -0.04 & 0.03 & -0.13 & 0.06 & -0.13 & -0.10 & -0.16 \\
\hline & $(0.11)$ & $(0.08)$ & $(0.11)$ & $(0.06)$ & $(0.08)$ & $(0.08)$ & $(0.08)$ \\
\hline \multirow[t]{2}{*}{$\mathrm{FC}$} & -0.02 & -0.06 & 0.09 & -0.05 & 0.13 & 0.10 & 0.14 \\
\hline & $(0.12)$ & $(0.09)$ & $(0.12)$ & $(0.06)$ & $(0.08)$ & $(0.09)$ & $(0.08)$ \\
\hline Adjusted $R^{2}$ & 0.02 & 0.02 & 0.10 & 0.51 & 0.56 & 0.50 & 0.53 \\
\hline
\end{tabular}

${ }^{*} p<.10,{ }^{* *} p<.05,{ }^{* * *} p<.01,{ }^{a}$ Beta coefficients with standard errors in parenthesis

In addition, productivity improvement is an important indicator of explaining value creation and driving business survival. It has a critical positive effect on value creation $(b=$ $1.09, \mathrm{p}<0.01 ; \mathrm{b}=0.55, \mathrm{p}<0.01)$ and business survival $(\mathrm{b}=0.58$, $\mathrm{p}<0.05 ; \mathrm{b}=0.40, \mathrm{p}<0.03)$. Thus, productivity improvement significantly leads to value creation and business survival. Firms with successful productivity improvement can increase superior value creation and gain long-term business survival. In this study, productivity improvement explicitly increases the ratio growth of outputs to inputs through utilization, efficiency, effectiveness, and quality of useful resources, including materials, labors, machines, and funding to produce qualified goods and services (Geum, Shin, \& Park, 2011).
It can help find and eliminate causes of mistakes and defects in business processes by focusing on desired outputs (Desai, 2013). It also utilizes input resources in a transformation process to co-create value with customers (Zolnowski, Semmann, Amrou, \& Bohmann, 2013). Hence, productivity improvement is essential for increasing firm value, encouraging current profitability and promoting future performance and long-term survival. Therefore, Hypotheses $2 \mathrm{a}-2 \mathrm{~b}$ are supported.

For verifying the mediating effects of this study according to Baron and Kenny (1986), internal control effectiveness is critically related to productivity improvement $(\mathrm{b}=0.40, \mathrm{p}<0.08)$ as shown in Table 5 . 
Kornchai PHORNLAPHATRACHAKORN, Khajit NA KALASINDHU /

Table 6: A summary of hypotheses testing results

\begin{tabular}{|c|c|c|c|}
\hline Hypotheses & Relationships & SEM & OLS \\
\hline $\mathrm{H} 1 \mathrm{a}$ & $\begin{array}{l}\text { Internal control effectiveness has } \\
\text { a positive effect on productivity } \\
\text { improvement. }\end{array}$ & Supported & Supported \\
\hline $\mathrm{H} 1 \mathrm{~b}$ & $\begin{array}{l}\text { Internal control effectiveness has a } \\
\text { positive effect on value creation. }\end{array}$ & Not supported & Not supported \\
\hline $\mathrm{H} 1 \mathrm{c}$ & $\begin{array}{l}\text { Internal control effectiveness has a } \\
\text { positive effect on business survival. }\end{array}$ & Supported & Supported \\
\hline $\mathrm{H} 2 \mathrm{a}$ & $\begin{array}{l}\text { Productivity improvement has a positive } \\
\text { effect on value creation. }\end{array}$ & Supported & Supported \\
\hline $\mathrm{H} 2 \mathrm{~b}$ & $\begin{array}{l}\text { Productivity improvement has a positive } \\
\text { effect on business survival. }\end{array}$ & Supported & Supported \\
\hline H3 & $\begin{array}{l}\text { Productivity improvement mediates the } \\
\text { internal control effectiveness-business } \\
\text { survival relationships. }\end{array}$ & Supported & Supported \\
\hline $\mathrm{H} 4$ & $\begin{array}{l}\text { Value creation has a positive impact on } \\
\text { business survival. }\end{array}$ & Supported & Supported \\
\hline H5 & $\begin{array}{l}\text { Value creation mediates the internal } \\
\text { control effectiveness-business survival } \\
\text { relationships. }\end{array}$ & Not supported & Not supported \\
\hline
\end{tabular}

Accordingly, productivity improvement is possible to become the mediator of the internal control effectivenessbusiness survival relationships. Next, both internal control effectiveness and productivity improvement are considered as the independent variables at the same time while business survival is the dependent variable of the study. The results show that internal control effectiveness has no effect on business survival $(b=0.24, p<0.12)$, but productivity improvement has a significant influence on business survival $(b=0.68, p<0.01)$. Similarly, internal control effectiveness significantly affects productivity improvement $(b=0.20$, $\mathrm{p}<0.09)$ while productivity improvement critically influences business survival $(b=0.58, p<0.05)$ in the same time as shown in Table 4 . Then, productivity improvement is a potential mediator of the internal control effectivenessbusiness survival relationships. Therefore, Hypothesis 3 is supported.

Similarly, value creation has a significant influence on business survival. It positively affects business survival $(b=0.57, p<0.05 ; b=0.61, p<0.01)$. In existing literature, value creation is the results of pooling and accumulating firms' heterogeneous resources and capabilities through developments of innovative products and services (Schneider $\&$ Sachs, 2017). It is beneficial to build and enhance in high levels of performance and success. Better value creation relates to greater performance and success and increase more survival and sustainability in an organization. Firms with outstanding value creation can achieve superior performance and sustainable survival. Thus, value creation has an important impact on business survival. It positively links to business survival. Therefore, Hypothesis 4 is supported.

To verify the mediating effects of value creation on the research relationships, internal control effectiveness has no influence on value creation $(b=0.06, p<0.63 ; b=0.29$, $\mathrm{p}<0.11)$ as shown in Tables 4-5. According to Baron and Kenny (1986), when the effects of internal control effectiveness on value creation are not significant, value creation could not become the mediator of the internal control effectiveness-business survival relationships. Then, value creation is not a mediator of the internal control effectiveness-business survival relationships. Therefore, Hypothesis 5 is not supported.

Table 6 presents a summary of the research results. In summary, internal control effectiveness has a significant determinant of both productivity improvement and business survival. Also, productivity improvement importantly leads to value creation and business survival and it explicitly mediates the internal control effectiveness-business survival relationships. In addition, value creation critically relates to business survival, but it does not mediate the research relationships. Likewise, both SEM and OLS methods have presented the same results of the study. 


\section{Contributions and Directions for Future Research}

\subsection{Theoretical Contribution}

This study pays attention to the importance of internal control effectiveness in an organization. It attempts to understand the concepts and roles of internal control effectiveness and integrate the associations among internal control effectiveness, productivity improvement, value creation, and business survival. This study also confirms existing literature of the dynamic capability theory in which firms implement internal control effectiveness as a valuable source of their competitive advantage and performance. In this study, internal control effectiveness is a key determinant of explaining productivity improvement and business survival. Best internal control effectiveness is positively related to great productivity improvement and sustainable business survival.

In existing literature, both secondary data and primary are empirically utilized to measure constructs in a study. Here, the primary data via using the questionnaire as the research tool is applied to collect the data. The internal audit executives are the key informants to answer all questions through their practices and perceptions of internal control activities and outcomes. However, some relationship results of this study are not supported. Accordingly, this may be a limitation of the study. To verify the current study, future research may utilize the second data via a quantitative data in order to prove the aforementioned relationships. The results of the future research may fulfill the current study and expand the explanations and understandings of the research objectives.

To expand the current study of the internal control effectiveness-business survival relationships, future research may need to review the concepts and characteristics of value creation and investigate the roles of value creation in the research relationships. To increase the benefits of the study, future research may also need to find efficient moderators in order to generate and add the utilization of research results and apply these results to real conditions, situations and circumstances. Likewise, future research may need to consider a comparative study as a research method in order to generalise the research results by gathering data from other businesses and larger populations in Thailand and other countries. Lastly, future research may need to improve a response rate of the study in order to confirm the research results by finding a way to the increased response rate.

\subsection{Managerial Contribution}

This study is beneficial to firms' doing business activities. Internal control effectiveness plays a significant role in explaining their outcomes, namely performance, success, survival, and sustainability. Accordingly, firms need to consider and utilize internal control effectiveness as valuable strategic mechanism to define their techniques and guidelines for competing in rapidly changing business environments. They must allocate their resources, assets and capabilities to internal control systems and invest advanced innovations and technologies to these systems. Effectiveness of the internal control systems can help generate their benefits. Moreover, firms need to enhance their employees in understanding, learning and implementing the concepts of the internal control systems. Thus, training and studying in these concepts are important. Employees' good knowledge can utilize the internal control systems well. Accordingly, they can use them to create their outstanding organizational efficiency, productivity and effectiveness and improve and increase their competitiveness, success and sustainability.

\section{Conclusion}

Internal control systems are valuable strategic mechanisms in enhancing firms' performance and success in rapidly competitive business environments. Thus, the effectiveness of internal control system is important for successfully doing businesses. In this study, internal control effectiveness is proposed as a key determinant of firms' productivity improvement, value creation and business survival. This study examines the impacts of internal control effectiveness on business survival of food businesses in Thailand. Here, 155 food businesses in Thailand are the samples of the study. To investigate the research relationships, both structural equation model and multiple regression analysis are considered as usable methods of the study. According to the research results, internal control effectiveness is positively related to productivity improvement and business survival, but it does not influence value creation. Also, productivity improvement has an important positive influence on value creation and business survival while value creation positively affects business survival. To verify the mediating effects of the research relationships, only productivity improvement mediates the internal control effectiveness-business survival relationship, but value creation does not mediate the research relationships. In summary, internal control effectiveness becomes a potential business technique and strategy which firms can utilize it for achieving superior success and sustainability in future and long-term operations. To expand the current study, future research needs to review and investigate the concepts of value creation, find efficient moderators in adding the utilization of research results, implement a comparative study to generalize the research results, and improve a response rate of the study. 


\section{References}

Aaker, D. A., Kumar, V., \& Day, G. S. (2001). Marketing research. Hoboken, NJ: John Wiley \& Sons.

Aimran, A. N., \& Ahmad, S. (2013). A comparison between ordinary least square (OLS) and structural equation modeling (SEM) methods in estimating the influencial factors of 8th grades student's mathematics achievement in Malaysia. International Journal of Scientific and Engineering Research, 4(7), 717-722.

Anh, T. C., Thi, L. H. T., Quang, H. P., \& Thi, T. T. (2020). Factors influencing the effectiveness of internal control in cement manufacturing companies. Management Science Letters, 10(1), 133-142.

Armstrong, J. S., \& Overton, T. S. (1977). Estimating non-response bias in mail surveys. Journal of Marketing Research, 14(3), 396-402.

Baltova, S., \& Baltov, M. (2017). Value creation and value cocreation in professional business services: a challenge in digital environment. Bulgarian Journal of Business Research, 3, 31-44.

Baron, R. M., \& Kenny, D. A. (1986). The moderator-mediator variable distinction in social psychological research: conceptual, strategic and statistical considerations. Journal of Personality and Social Psychology, 51, 1173-1182.

Bentler, P. M. (1990). Comparative fit indices in structural models. Psychological Bulletin, 107, 238-246.

Bollen, K. A., \& Long, J. S. (1993). Testing structural equation models. Thousand Oaks, CA: Sage Publications.

Bouncken, R. B., Fredrich, V., Kraus, S., \& Ritala, P. (2020). Innovation alliances: balancing value creation dynamics, competitive intensity and market overlap. Journal of Business Research, 112, 240-247.

Byrne, B. M. (1998). Structural equation modeling with LISREL, Prelis and Simplis: basic concepts, applications and programming. Mahwah NJ: L. Erlbaum Associates.

Chang, S., Yen, D., Chang, I., \& Jan, D. (2014). Internal control framework for a compliant ERP system. Information and Management, 51, 187-205.

Chen, X., Ma, Z., Shi, J., Tu, B., \& Xu, S. 2020. Corporate social responsibility and unsecured debt: evidence from China. Journal of Asian Finance, Economics and Business, 7(11), 1-11. https://doi.org/10.13106/jafeb.2020.vol7.no11.001

Chen, Y., Smith, A. L., Cao, J., \& Xia, W. (2014). Information technology capability, internal control effectiveness and audit fees and delays. Journal of Information Systems, 28(2), 149180 .

Churchill, G. A., Jr (1979). A paradigm for developing better measures of marketing constructs. Journal of Marketing Research, 16(February), 64-73.

Dao, V. T. (2019). The battle for survival: innovating firms'strategic signaling behaviors and their impacts on business success during the shakeout period after the standards war. The Journal of High Technology Management Research, 30(1), 70-81.
Dave, Y., \& Sohani, N. (2019). Improving productivity through Lean practices in central India-based manufacturing industries. International Journal of Lean Six Sigma, 10(2), 601-621.

Desai, D. A. (2013). Rediscovering six sigma: comparison with other quality and productivity improvement techniques. Productivity, 25(3), 295-301.

Franzoni, S., \& Pelizzari, C. (2019). Rainfall financial risk assessment in the hospitality industry. International Journal of Contemporary Hospitality Management, 31(3), 1104-1121.

Geum, Y., Shin, J., \& Park, Y. (2011). FMEA-based portfolio approach to service productivity improvement. The Service Industries Journal, 31(11), 1825-1847.

Hair, J. F., Black, W. C., Babin, B. J., \& Anderson, R. E. (2010). Multivariate data analysis: a global perspective $\left(7^{\text {th }} \mathrm{ed}\right)$. Upper Saddle River, NJ: Person Prentice Hall.

Hazami-Ammar, S. (2019). Internal auditors' perceptions of the function's ability to investigate fraud. Journal of Applied Accounting Research, 20(2), 134-153.

Herda, D. N., \& Lavelle, J. J. (2012). The auditor-audit firm relationship and its effect on burnout and turnover intention. Accounting Horizons, 26(4), 707-723.

Husnaini, W., \& Basuki, B. 2020. ASEAN corporate governance scorecard: sustainability reporting and firm value. Journal of Asian Finance, Economics and Business, 7(11), 315-326. https://doi.org/10.13106/jafeb.2020.vol7.no11.315

Jacobs, B. W., Kraude, R., \& Narayanan, S. (2016). Operational productivity, corporate social performance, financial performance, and risk in manufacturing firms. Production and Operations Management, 25(12), 2065-2085.

Kahkonen, A., \& Lintukangas, K. (2012). The underlying potential of supply management in value creation. Journal of Purchasing and Supply Management, 18, 68-75.

Kline, R. B. (1998). Principles and practices of structural equation modeling. New York, NY: The Guilford Press.

Korunka, C., Kessler, A., Frank, H., \& Lueger, M. (2010). Personal characteristics, resources and environments as predictors of business survival. Journal of Occupational and Organizational Psychology, 83, 1025-1051.

Krishnan, G. V., \& Yu, W. (2012). Do small firms benefit from auditor attestation of internal control effectiveness?. Auditing: A Journal of Practice and Theory, 34(1), 115-137.

Lari Dashtbayaz, M., Salehi, M., \& Safdel, T. (2019). The effect of internal controls on financial reporting quality in Iranian family firms. Journal of Family Business Management, 9(3), 254-270.

Lansiluoto, A., Jokipii, A., \& Eklund, T. (2016). Internal control effectiveness - a clustering approach. Managerial Auditing Journal, 31(1), 5-34.

Matthyssens, P., Bocconcelli, R., Pagano, A., \& Quintens, L. (2016). Aligning marketing and purchasing for new value creation. Industrial Marketing Management, 52, 60-73.

Neter, J., Wasserman, W., \& Kutner, M. H. (1985). Applied linear statistical models: regression, analysis of variance, and 
experimental designs ( $2^{\text {nd }}$ ed). Homewood, IL: Richard D. Irwin.

Nunnally, J. C., \& Bernstein, I. H. (1994). Psychometric theory. New York, NY: McGraw-Hill.

Osborne, J. W., \& Waters, E. (2001). Four assumptions of multiple regression that researchers should always test. Practical Assessment, Research, and Evaluation, 8(2), 1-5.

Sarstedt, M., Hair, J. F., Ringle, C. M., Thiele, K. O., \& Gudergan, S. P. (2016). Estimation issues with PLS and CBSEM: where the bias lie! Journal of Business Research, 69(10), 3998-4010.

Schneider, T., \& Sachs, S. (2017). The impact of stakeholder identities on value creation in issue-based stakeholder networks. Journal of Business Ethics, 144, 41-57.

Stafford, K., Danes, S. M., \& Haynes, G. W. (2013). Long-term family firm survival and growth considering owning family adaptive capacity and federal disaster assistance receipt. Journal of Family Business Strategy, 4, 188-200.
Teece, D. J., Pisano, G., \& Shuen, A. (1997). Dynamic capabilities and strategic management. Strategic Management Journal, 18(7), 509-533.

Tran, Q. T., Lam, T. T., \& Luu, C. D. 2020. Effect of corporate governance on corporate social responsibility disclosure: empirical evidence from Vietnamese commercial banks. Journal of Asian Finance, Economics and Business, 7(11), 327-333. https://doi.org/10.13106/jafeb.2020.vol7.no11.327

Wang, J. (2015). An Empirical Study of the effectiveness of internal control and influencing factors. Management and Engineering, $18,8-13$.

Zacharias, N., Nijssen, E. J., \& Stock, R. M. (2016). Effective configurations of value creation and capture capabilities: extending treacy and Wiersema's value disciplines. Journal of Business Research, 39, 4121-4131.

Zolnowski, A., Semmann, M., Amrou, S., \& Bohmann, T. (2013). Identifying opportunities for service productivity improvement using a business model lens. The Service Industries Journal, 33(3-4), 409-425. 
Appendix A: Measurement of all variables

\begin{tabular}{|c|c|c|c|}
\hline Items & $\begin{array}{l}\text { Factor } \\
\text { Loading }\end{array}$ & $\begin{array}{l}\text { Item-total } \\
\text { correlation }\end{array}$ & $\begin{array}{l}\text { Cronbach } \\
\text { Alpha }\end{array}$ \\
\hline $\begin{array}{l}\text { Internal Control Effectiveness } \\
\text { IC1: Firms believe that effective internal control system can help enhance } \\
\text { operational practices, functions and activities to meet organizational } \\
\text { objectives well. }\end{array}$ & $\begin{array}{l}0.41-0.86 \\
0.80\end{array}$ & $\begin{array}{l}0.43-0.62 \\
0.62\end{array}$ & 0.80 \\
\hline $\begin{array}{l}\text { IC2: Firms have implemented the internal control system in an organization } \\
\text { for assuring all plans that are efficiently practiced. }\end{array}$ & 0.86 & 0.43 & \\
\hline $\begin{array}{l}\text { IC3: Firms have utilized the results of internal control assessment in } \\
\text { improving operational processes and methods objectively. }\end{array}$ & 0.41 & 0.42 & \\
\hline $\begin{array}{l}\text { IC4: Firms have provided awareness with capable internal control system } \\
\text { that can promote operational stability, growth and sustainability. }\end{array}$ & 0.81 & 0.46 & \\
\hline $\begin{array}{l}\text { IC5: Firms have paid attention on the utilization of internal control system in } \\
\text { giving a guideline for an organization's successful operations in the current } \\
\text { and future aspects. }\end{array}$ & 0.64 & 0.61 & \\
\hline Productivity Improvement & $0.68-0.92$ & $0.40-0.56$ & 0.90 \\
\hline $\begin{array}{l}\text { PI1: Firms can use their capabilities in increasing organizational } \\
\text { improvement. }\end{array}$ & 0.68 & 0.55 & \\
\hline $\begin{array}{l}\text { PI2: Firms have the result growth of their operations and managements } \\
\text { under the uses of appropriate resources and capabilities. }\end{array}$ & 0.87 & 0.52 & \\
\hline $\begin{array}{l}\text { PI3: Firms can achieve best organizational goals by using lowest costs and } \\
\text { expenses. }\end{array}$ & 0.92 & 0.40 & \\
\hline $\begin{array}{l}\text { PI4: Firms have the growth rate of revenues to costs and expenses } \\
\text { continuously. }\end{array}$ & 0.88 & 0.56 & \\
\hline $\begin{array}{l}\text { PI5: Firms have increasing outstanding and different operations compared } \\
\text { to targeted important competitors. }\end{array}$ & 0.90 & 0.51 & \\
\hline Value creation & $0.73-0.91$ & $0.50-0.77$ & 0.87 \\
\hline $\begin{array}{l}\text { VC1: Firms can create revenues, benefits and advantages in an } \\
\text { organization. }\end{array}$ & 0.83 & 0.77 & \\
\hline VC2: Firms can develop best operational competencies in an organization. & 0.91 & 0.58 & \\
\hline $\begin{array}{l}\text { VC3: Firms can provide a creativity of best management system in } \\
\text { promoting goal achievements. }\end{array}$ & 0.84 & 0.50 & \\
\hline $\begin{array}{l}\text { VC4: Firms have committed with creativity, of objective organizational } \\
\text { values. }\end{array}$ & 0.74 & 0.51 & \\
\hline $\begin{array}{l}\text { VC5: Firms can respond to the needs of customers and other stakeholders } \\
\text { in all situations. }\end{array}$ & 0.73 & 0.69 & 0.89 \\
\hline Business survival & $0.77-0.96$ & $0.57-0.80$ & \\
\hline BS1: Firms have profits and profitability congruent with their goals. & 0.89 & 0.78 & \\
\hline BS2: Firms can meet sale goals and achieve extra revenue goals. & 0.91 & 0.80 & \\
\hline BS3: Firms continuously have the sale growth from effective operations. & 0.96 & 0.57 & \\
\hline $\begin{array}{l}\text { BS4: Firms can achieve the growth rate of operational profits within } \\
\text { organizational prediction. }\end{array}$ & 0.79 & 0.76 & \\
\hline $\begin{array}{l}\text { BS5: Firms can create new products and services for responding the needs } \\
\text { of customers and markets. }\end{array}$ & 0.77 & 0.75 & \\
\hline $\begin{array}{l}\text { BS6: Firms can make best maintenance of existing customers through } \\
\text { building satisfaction to the customers. }\end{array}$ & 0.89 & 0.69 & \\
\hline $\begin{array}{l}\text { BS7: Firms can increase the numbers of new valuable customers that } \\
\text { positively affect their sales and revenues. }\end{array}$ & 0.90 & 0.71 & \\
\hline
\end{tabular}

